\title{
LAPAROSCOPIC RADICAL PROSTATECTOMY: A SINGLE CENTER EXPERIENCE
}

\author{
Bashkim Shabani ${ }^{1}$, Ognen Ivanovski ${ }^{1}$, Slobodan Gurmeshevski ${ }^{1}$, Gordana Petrushevska ${ }^{2}$, \\ Sašo Dohcev ${ }^{1}$, Sotir Stavridis ${ }^{1}$, Oliver Stankov ${ }^{1}$
}

\begin{abstract}
Minimally invasive techniques including robotic-assisted and laparoscopic radical prostatectomy have become the preferred approach for operative treatment of prostate cancer. The aim of this study was to evaluate and compare results of laparoscopic radical prostatectomy (LRP) and open retropubic radical prostatectomy (ORRP) for localised prostate cancer, in terms of safety, efficacy and oncological outcome.

A total of 123 radical prostatectomies (RPs) for low-risk localised prostate cancer were performed between January 2016 and June 2019 at the University Clinic of Urology Skopje. Of these, $61(49.6 \%)$ were LRP and 62 (50.4\%) ORRP, mean patients' age was 54 years (33 to 67). Indications for operative procedure included: pathohistological finding of prostate cancer, age $\leq 70$ years, PSA $<10 \mathrm{ng} / \mathrm{ml}$, Gleason score $\leq 7(3+3$ or $3+4)$, negative bone scintigraphy, stage $\leq \mathrm{T} 2 \mathrm{a}$, NO, MO. All patients were assessed regarding the demographic data, PSA level, Gleason score, operative time, conversion to open surgery for LRP, blood loss, intra and post operative complications, catheter removal, number blood transfusion, hospital stay and oncological outcomes. LRP proved superior to ORRP, resulting in a shorter operating time, less blood loss $(p<0.5)$, shorter time to resumption of oral intake, shorter postoperative hospital stay $(p<0.5)$, and less analgesic requirements. In terms of oncological outcomes, we observed less positive margins in the LRP group $(p<0.5)$. Our results indicate that although both operative techniques represent safe procedures, offering good quality of operation, in our series, LRP was superior in terms of safety, efficacy and oncological outcomes.
\end{abstract}

Acta Medica Medianae 2020;59(3):13-19.

Key words: prostate cancer, laparoscopic radical prostatectomy, open retropubic radical prostatectomy

\footnotetext{
${ }^{1}$ University Clinic of Urology, Medical Faculty, University Ss Cyril and Methodius, Skopje, North Macedonia

${ }^{2}$ Institute of Pathology, Medical Faculty, University Ss Cyril and Methodius, Skopje, North Macedonia
}

Contact: Bashkim Shabani

17 Vodnjanska Str., 1000 Skopje, North Macedonia

E-mail: bashkimshabani7@gmail.com

\section{Introduction}

Recent epidemiological data show that at the end of 2018, prostate cancer was second in respect to all cancers in the male population, with an incidence that varies by region, from the age-standardized rate of 11.5/100 000 in Asia to 62.1/100 000 in Europe $(1,2)$.There are several treatment modalities for patients diagnosed with localized prostate cancer. According to EAU Guidelines 2019, it includes deferred treatment (active surveillance/ watchful waiting) and active (curative) treatment. Active treatment encompasses a wide range of options, including radical prostatectomy, external beam radiation therapy, brachytherapy (both high and low dose), hormonal therapy, cryotherapy, high-intensity focused ultrasound, focal therapy (3). With respect to all of these therapeutic options, radical prostatectomy is the therapeutic option of choice for patients with localized prostate cancer whose survival is expected to be longer than 10 years (4). According to a 2014 study by Bill Axelson et al., radical prostatectomy with respect to it significantly reduces CSS, with a relative risk of 0.56 (5). The same authors said in a 2018 study that the survival benefit for patients with localized prostate cancer who underwent radical prostatectomy was at least 2.9 years (6). In regard to lymph node dissection following RP, it has been stated that low-risk disease is rarely associated with nodal involvement (7).

Open radical prostatectomy has long been the only operative technique for the treatment of prostate cancer. It has undergone many modifications 
and among them is the anatomical retropubic radical prostatectomy, which he introduced into the clinical practice of Walsh in 1982, and which is characterized by a better knowledge of hemostasis and cavernous nerve preservation (8). Further progress was directed towards reducing the invasiveness of the procedure, and at the end of the $20^{\text {th }}$ century the technique of laparoscopic radical prostatectomy was promoted, with a positive growth trend over the coming years $(9,10)$. Drawbacks of the laparoscopic technique, which are primarily related to limitations in performing certain manual operations and movements, the absence of a third dimension, as well as a long learning curve, led to the emergence of a new operative technique - robotic assisted radical laparoscopic prostatectomy (RALP), which had been introduced in 2000 by Binder et al. (11). According to the results of recently published studies, as well as the EAU Guidelines, it cannot be stated with certainty that any of the above techniques has clinically significant advantages over the other two in terms of oncological and functional results (12).

The aim of this study was to evaluate and compare results of open retropubic radical prostatectomy (ORRP) and laparoscopic radical prostatectomy (LRP) for localised prostate cancer, in terms of safety, efficacy and oncological outcome.

\section{Patinents and methods}

A total of 123 radical prostatectomies (RPs) for low-risk localised prostate cancer were performed between January 2016 and June 2019 at the University Clinic of Urology in Skopje. Of these, 61 (49.6\%) were LRP and 62 (50.4\%) ORRP, mean patients' age was 54 years (33 to 67). Indications for operative procedure included: pathohistological finding of prostate cancer, age $\leq 70$ years, PSA < $10 \mathrm{ng} / \mathrm{ml}$, Gleason score $\leq 7(3+3$ or $3+4)$, negative bone scintigraphy, stage $\leq \mathrm{T} 2 \mathrm{a}, \mathrm{NO}, \mathrm{MO}$. All patients were assessed regarding the demographic data, PSA level, Gleason score, operative time, conversion to open surgery for LRP, blood loss, intra and post operative complications, catheter removal, number of blood transfusions, hospital stay and oncological outcomes. Mean follow-up was 6 months (5 to 36). All patients underwent standardized preoperative procedure of our clinic, including: complete blood count, biochemical analysis, urine, urine culture, PSA, multislice computerized abdomino-pelvic tomography, histopathological result of transrectal ultrasound guided prostate biopsy, cardiac and anesthesia evaluation, urological evaluation. Statistical analysis was estimated by using of Fisher's test and Hisquared test.

Surgical technique of ORRP was as described by Walsh (8). Surgical technique of laparoscopic prostatectomy was performed by the same surgical team, as follows: an infraumbilical incision was made with approximately $1 \mathrm{~cm}$ of length in the midline. Incision of rectus fascia was performed on the linea alba. Creation of preperitonenal space was performed using the fingers and the camera and then insufflation with $\mathrm{CO}_{2}$ tension of $12 \mathrm{mmHg}$. We intro- duced the 0-grade optics through the infraumbilical port and additional four ports were placed under visual control. Two $11 \mathrm{~mm}$ trocars were inserted on the pararectal lateral border while two $5 \mathrm{~mm}$ were placed half way between the anterior-superior iliac crest and para rectal trocars. During the procedure we used only bipolar tools (clamps and grasps) including the forceps for the operator's left hand. We found this tool comfortable for both dissection and coagulation. After entering into the retropubic space, dissection of the prevesical space of Retzius was performed in a deliberate manner. The superficial dorsal vein, was coagulated with bipolar electrocautery. Subsequently, the endopelvic fascia was cleaned bilaterally. The endopelvic fascia was incised on both sides by bipolar scissors. The fascial incision was carried distally up to the most lateral puboprostatic ligament. The fibers should not be divided close to the prostate in order to avoid injury of large veins that cross on the latero-posterior side of the prostate. Visualization of the prostate apex was the end point of this dissection. The apex of the prostate was defined bilaterally. The deep venous complex of Santorini (DVC) was ligated with a 2-0 vicryl suture. In order to locate the bladder neck, Foley catheter was pulled and inflated with $10-15 \mathrm{ml}$. The bladder was incised at its junction with the prostate with bipolar forceps. The urethra was dissected at its anterior and lateral aspect and then transversally transected with scissors. The Foley catheter was removed and replaced by a ureteric stent (ch 16), which provided a good visualization of the bladder. This was an important step in order to ensure good preservation of the bladder neck. Next, by pulling the prostate upward in the direction of the pubic symphysis, we were able to uncover vertical fibers of the anterior layer of Denonvilliers' fascia. Its incision showed the retrovesical space in which the vas deferens and seminal vesicals are located. During the preparation of the seminal vesicles, we performed a good hemostasis of the medially situated vessels. The posterior lip of the bladder neck was grasped with forceps and lowered to provide access to the interprostatorectal plane. The vertical fibers of the anterior plane of Denonvillier's fascia covering the seminal vesicles were incised. The ampoule of the right vas deferens was sectioned after coagulation with cold scissors or clipped with a Hemo-lock clip. A large grip was used to simultaneously coagulate the anterior deferential artery. The seminal vesicle was dissected circumferentially from the base to the apex, taking care to control the vessels. The lateral pedicle of the seminal vesicle was dissected and coagulated following the inferior pedicle dissection and coagulation. We proceeded with the dissection of the lateral surface of the prostate. After sectioning the neurovascular bundle (NVB) and local hemostasis with both bipolar forceps and Hem-olock clips, we continued with prostate apex section. Dissection of the apex was started with retraction of the preprostatic tissues using unipolar scissors. The urethra was reached gradually by incising the tissues covering the anterior surface of the urethra. The stent was advanced to make the urethra more 
prominent. The posterior surface of the urethra was sectioned at the end. Fibers of the rectourethral muscle were sectioned revealing the plane of the rectum. After freeing prostate we performed the urethrovesical V anastomosis. Prostate gland is placed in catch and extracted trough right pararectus trocar port. Afterward, trocar was taken out and inserted again in the same port beside the endobag.

The urethrovesical anastomosis was performed using a running continuous unidirectional barbed (V-Loc ${ }^{\circledR} 180$ ) running sutures. The right tail of the suture started from $5 \mathrm{~h}$ to $12 \mathrm{~h}$ position. The left tail of the suture started from $7 \mathrm{~h}$ to $12 \mathrm{~h}$ position. Assurance of watertight closure with an intraoperative $150-200$ cc saline was performed in all cases. Finally a Foley catheter ch 16 was placed. Once the vesicourethral anastomosis was completed, a $16 \mathrm{~F}$ drain was introduced and fixed. The drain was placed in the Retzius space. The endobag was extracted by applying traction and rotation movements throughout the right port followed with incision of rectus fascia and distraction of rectus muscle fiber that ease the extraction.

\section{Results}

Basic demographic data and perioperative parameters are listed in Table 1 . There were no statistical difference between LRP and ORRP in terms of number of patients, mean age (65.46 \pm 3.3 and $65.3 \pm 2.5$, respectively), clinical stage, preoperative PSA values (6.6 \pm 1.8 and $7.7 \pm 1.6$, respectively), as well as GS values of biopsy and final operative specimen. However, positive surgical margins were statistically different in favor of ORRP group $(p<0.05)$.

Table 1. Perioperative parameters

\begin{tabular}{|c|c|c|c|}
\hline & & & \\
\hline & LRP & ORRP & $\mathrm{p}$ \\
\hline Number of patients & 61 & 62 & \\
\hline Age & $65.46 \pm 3.3$ & $65.3 \pm 2.5$ & NS \\
\hline Prostate volume & $68 \pm 22$ & $72 \pm 41$ & NS \\
\hline Clinical stage & $\leq \mathrm{T} 2 \mathrm{a}$ & $\leq \mathrm{T} 2 \mathrm{a}$ & \\
\hline Preoperative PSA (ng/ml) & $6.6 \pm 1.8$ & $7.7 \pm 1.6$ & NS \\
\hline \multicolumn{4}{|l|}{ Gleason score (GS) (biopsy) } \\
\hline$\leq 6$ & 37 & 42 & NS \\
\hline $7(3+4)$ & 24 & 20 & NS \\
\hline \multicolumn{4}{|l|}{ GS (postoperative) } \\
\hline$\leq 6$ & 29 & 39 & NS \\
\hline $7(3+4)$ & 32 & 23 & NS \\
\hline
\end{tabular}

Data on intraopereative and postoperative parameters showed that mean surgical time was similar in both groups, with no statistical difference (126.18 \pm 19.5 and $126.66 \pm 12.3$, respectively). Patients who underwent ORRP had higher blood loss and that difference is statistically significant (355.17 \pm 57.75 vs. $275.4 \pm 39.79$, separately, $p<0.5)$. It was observed that both period of postoperative hospitalization as well as postoperative catheter removal were shorter in LRP group ( $6.2 \pm 0.4$ vs. $7.43 \pm 0.49, \mathrm{p}<0.05$; and $6.2 \pm 0.4$ vs. $7.43 \pm$ 0.49, p < 0.05) (Table 2).

Table 2. Intra- and postoperative parameters

\begin{tabular}{|l|c|c|c||}
\cline { 2 - 4 } \multicolumn{1}{c|}{} & LRP & ORRP & $\mathrm{p}$ \\
\hline Mean surgical time (minutes) & $126.18 \pm 19.5$ & $126.66 \pm 12.3$ & $\mathrm{NS}$ \\
\hline Blood loss $(\mathrm{ml})$ & $275.4 \pm 39.79$ & $355.17 \pm 57.75$ & $\mathrm{p}<0.5$ \\
\hline $\begin{array}{l}\text { Postoperative hospitalization } \\
\text { (days) }\end{array}$ & $6.2 \pm 0.4$ & $7.43 \pm 0.49$ & $\mathrm{p}<0.5$ \\
\hline Catheter removal (days) & $6.2 \pm 0.4$ & $7.43 \pm 0.49$ & $\mathrm{p}<0.5$ \\
\hline
\end{tabular}


When perioperative complications according to Clavien-Dindo classification have been analyzed, there were 11 grade I events $(18 \%)$ in the LRP group and $8(12.9 \%)$ in the ORRP group ( $p>0.05)$. Grade II that refers to intraoperative blood loss was more frequent in the ORRP $(12 \%$ vs. $27 \%, \mathrm{p}<$ $0.05)$. There was $1(1.6 \%)$ LRP event of grade IIIa and $2(3.2 \%)$ ORRP ( $p>0.5$ ). In all cases, urethral catheter was dropped out, so recatheterization was performed endoscopically. In one case (1.6\%) we observed rectal injury during LRP (grade IIIb), so the laparoscopic intervention had been converted into the open. Rectal injury was completely repaired, with no additional complications, and the patient was discharged from the hospital on day 12. Complications of higher grade (IV and V) were not observed. Data on perioperative complications according to Clavien-Dindo classification are summarized in Table 3.

Table 3. Perioperative complications (Clavien-Dindo classification)

\begin{tabular}{||l||c|c||c|c||c||}
\hline \multicolumn{1}{||c||}{ Procedure } & \multicolumn{2}{c||}{ LRP $(\mathrm{n}=61)$} & \multicolumn{2}{c||}{ ORRP $(\mathrm{n}=62)$} & $\mathrm{p}$ \\
\hline Patients & No & $\%$ & No & $\%$ & \\
\hline \hline Grade I & 11 & 18 & 8 & 12.9 & $\mathrm{p}>0.05$ \\
\hline Grade II & 7 & 12 & 17 & 27 & $\mathrm{p}<0.05$ \\
\hline Grade IIIa & 1 & 1.6 & 2 & 3.2 & $\mathrm{p}>0.05$ \\
\hline Grade IIIb & 1 & 1.6 & - & - & $\mathrm{p}>0.05$ \\
\hline Grade IVa & - & - & - & - & \\
\hline Grade IVb & - & - & - & - & \\
\hline Grade V & - & - & - & - & \\
\hline \hline
\end{tabular}

Our results indicate that the histopathological finding of the positive surgical margin was significantly more common in the ORRP group (19.6\% vs. $35.5 \%)$ and this difference is statistically significant $(p<0.5)$. Data on postoperative PSA values indicate that it was statistically significantly higher in the ORRP group, after 3 months and after 6 months, respectively $(0.0455 \pm 0.0524$ vs. $0.1708 \pm 0.23$ and $0.0781 \pm 0.0995$ vs. $0.115 \pm 0.0931$ ) (Table 4).

Table 4. Postoperative PSA and surgical margins

\begin{tabular}{||l|c|c|c||}
\cline { 2 - 4 } \multicolumn{1}{c|}{} & LRP $(\mathrm{n}=61)$ & ORRP $(\mathrm{n}=62)$ & $\mathrm{p}$ \\
\hline \hline Positive surgical margins (PSM) & $12(19.6 \%)$ & $22(35.5 \%)$ & $\mathrm{p}<0.5$ \\
\hline After 3 months & $0.0455 \pm 0.0524$ & $0.1708 \pm 0.23$ & $\mathrm{p}<0.5$ \\
\hline After 6 months & $0.0781 \pm 0.0995$ & $0.115 \pm 0.0931$ & $\mathrm{p}<0.5$ \\
\hline
\end{tabular}

\section{Discussion}

In this study, we presented our initial experience with LRP, with particular focus on results regarding perioperative complications and oncological outcomes, comparing these data with the data from the literature.To the best of our knowledge this is one of the first reports of this procedure in the Balkan region. Radical prostatectomy is a common curative treatment for localized prostate cancer. In this procedure, both oncological and functional outcomes based on health-related quality of life are taken into account. Radical prostatectomy has been developed from an open surgery to a laparoscopic procedure, with improved surgery made possible by magnification of the view of the anatomy around the prostate. Many authors have studied the effects of each of the radical prostatectomy surgery techniques (open, laparoscopic and robotic assisted). Laparoscopic surgery gained great popularity in the early $21^{\text {st }}$ century. The basic motives and reasons for developing this technique are contained in its minimal invasiveness. The effects of laparoscopic technique on tissue have been the subject of study in many studies. Thus, Fornara et al. (13) determined its benefits over open kidney tumor surgery, followed by a decreased inflammatory mediator response. Frakalanca et al. (14) studied the extent of tissue damage using open and laparoscopic radical prostatectomy techniques and found that there were 
very small differences in favor of laparoscopic technique. Similar conclusions were reached by Jurczok et al. in their prospective nonrandomized study (15). Open radical retropubic prostatectomy has its qualities, among which stand out especially: availability of performing in smaller centers, short duration of procedure, favorable cost of bone, relatively small invasiveness, possibility of working exclusively in extraperitoneal space, possibility of performing quality lymphadenectomy and relatively fast recovery (16, 17).

There were a total of 123 patients in our study series, 61 LRPs and 62 OORPs. There was no statistically significant difference in the number of subjects, their age and disease stage.

Preoperative PSA levels in both groups were below $10 \mathrm{ng} / \mathrm{ml}$ (low risk) and according to the recommendations by the EAU Guidelines, no lymphadenectomy was required. With regard to GS, no statistically significant differences were observed either in the preoperative biopsy appliance or in the definitive histopathological findings (18). Mean surgical time was similar in our two groups, with the period of time consistent with published data which had shown range from 100 to 151 minutes, as reported by Curtoet al. and Stolzenburg et al. $(19,20)$.

In regard to blood loss, in our series it was higher in ORRP group and it had been statistically significant. The range of blood loss was $235.61 \mathrm{ml}$ to $315.19 \mathrm{ml}$ in LRP and $297.42 \mathrm{ml}$ to $412.92 \mathrm{ml}$ in ORRP group. Average blood loss following LRP is reported to be from $200 \mathrm{ml}$ to $390 \mathrm{ml}$ (Curto, Goeman), and for ORRP $750 \mathrm{ml}$ to $1284 \mathrm{ml}(21,22)$. Transfusion rates in our series were in $27 \%$ of patients after ORRP and in 12\% after LRP. The difference is statistically significant and in favor of LRP group. It has been reported by several authors that transfusion rates ranges between $0.9 \%$ and $5.3 \%$ for $\operatorname{LRP}(19,23)$ and $9.7 \%$ and $29 \%$ for ORRP (22, 24). We believe that slightly higher transfusion rates as compared to the literature data, with real blood loss consistent with the results of published studies, are primarily the result of a learning curve and increased caution during postoperative recovery in the intensive care unit.
Regarding the duration of hospitalization and removal of the urethral catheter, in both cases the period was shorter in the LRP group and the difference is statistically significant. Several authors, including Bhayani et al. and Reissweileret al. stated that the benefits of minimally invasive radical prostatectomy techniques over open include lower blood loss, lower blood transfusion rates, less need for analgesia, and shorter hospitalization, catheterization and recovery $(25,26)$. In regard to perioperative complication rates, according to Clavien-Dindo classification, in our series there were higher rate of grade I, grade II, grade IIIa and grade IIIb complications in the ORRP group. However, statistical difference is observed only for grade II (transfusion rates). Other complications were present at a low rate and with no statistical differences between the observed groups, and are consonant with other series.

The oncologic outcome of surgery as seen through positive surgical margins in the definitive histopathologic specimen has been better after LRP because the PSM rate was $19.6 \%$, while in the ORRP group it was $35.5 \%$, and this difference had been statistically significant. The range of PSM varies from $4.7 \%$ to $18.3 \%$ after LRP, and from $51 \%$ to $76.6 \%$ after ORRP (24-29). It is evident that the incidence of PSM following ORRP is much higher over LRP, which is in accordance to our results. Finally, PSA values measured at 3 and 6 months postoperatively, although in both groups within the low risk range, were statistically significantly higher after ORRP. This can be explained by a more accurate resection line at LRP as well as a higher rate of PSM at ORRP.

\section{Conclusion}

Our results concur with other retrospective reviews comparing laparoscopic and open radical prostatectomy, demonstrating unequivocal advantages of LRP in terms of blood loss, blood transfusions, average rates of Clavien-Dindo complications of grade I to IIIb, duration of hospitalization, catheter removal, positive surgical margins and postoperative values of PSA at 3 and 6 months. 


\section{References}

1. Bray F, Ferlay J, Soerjomataram I, Siegel RL, Torre LA, Jemal A. Global cancer statistics 2018: GLOBOCAN estimates of incidence and mortality worldwide for 36 cancers in 185 countries. CA Cancer J Clin. 2018; 68(6):394-424. [CrossRef] [PubMed]

2. Ferlay J EM, Lam F, Colombet M, Mery L, Pineros M, Znaor A, Soerjomataram I. et al. Global cancer observatory: cancer today. Lyon, France: International Agency for Research on Cancer. Available from: https://gco.iarc.fr/today, Accessed 02 Februar

3. Mottet $\mathrm{N}$, van den Bergh RCN, Briers $\mathrm{E}$, Bourke $\mathrm{L}$, Cornford $P$, De Santis $M$, et al. Treatment. In: EAU EANM - ESTRO - ESUR - SIOG Guidelines on Prostate Cancer; Prostate cancer update March 2019, European Association of Urology 2019:38-53.

4. Heidenreich A, Bellmunt J, Bolla M, Joniau S, Mason $M$, Matveev $V$, et al. EAU Guidelines on prostate cancer. Part 1: Screening, diagnosis, and treatment of clinically localised disease. European Urology 2011; 59:61-71. [CrossRef] [PubMed]

5. Bill-Axelson A, Holmberg L, Garmo H, Rider J, Taari K, Busch $\mathrm{C}$, et al. Radical prostatectomy or watchful waiting in early prostate cancer. New England Journal of Medicine 2014;370:932-42. [CrossRef] [PubMed]

6. Bill-Axelson A, Holmberg L, Garmo H, Taari K, Busch C, Nordling $S$, Häggman $M$, Andersson SO, Andrén $O$, Steineck G, Adami HO, Johansson JE. Radical Prostatectomy or Watchful Waiting in Prostate Cancer - 29Year Follow-up. N Engl J Med 2018 Dec 13;379(24): 2319-2329. [CrossRef] [PubMed]

7. Heidenreich A, Pfister D. PSA persistence after radical prostatectomy needs more than standard therapeutic options to improve outcomes. BJU Int. $2019 \mathrm{Nov}$; 124(5):716-718. [CrossRef] [PubMed]

8. Walsh PC, Donker PJ. Impotence following radical prostatectomy: insight into etiology and prevention. J Urol 1982;128:492-7. [CrossRef] [PubMed]

9. Borgermann $C$, Loertzer $H$, Hammerer $P$, Fornara $P$, Graefen M, Rubben H. Problems, objective, and substance of early detection of prostate cancer [in German]. Urologe A 2010;49:181-9. [CrossRef] [PubMed]

10. Carvalhal GF, Smith DS, Mager DE, Ramos C, Catalona WJ. Digital rectal examination for detecting prostate cancer at prostate specific antigen levels of 4 $\mathrm{ng} / \mathrm{ml}$ or less. J Urol 1999;161:835-9. [CrossRef] [PubMed]

11. Binder J, Kramer W. Robotically assisted laparoscopic radical prostatectomy. BJU Int 2001;87:408-10. [CrossRef] [PubMed]

12. Coughlin GD, Yaxley JW, Chambers SK, Occhipinti S, Samaratunga $H$, Zajdlewicz $L$, et al. Robot-assisted laparoscopic prostatectomy versus open radical retropubic prostatectomy: 24-month outcomes from a randomised controlled study. Lancet Oncol 2018;19: 1051. [CrossRef] [PubMed]

13. Fornara $P$, Zacharias $M$. Minimal invasiveness of laparoscopic radical prostatectomy: reality or dream? AktuelleUrol 2004;35:395-405. [CrossRef] [PubMed]

14. Fracalanza S, Ficarra V, Cavalleri S, Galfano A, Novara G, Mangano A, et al. Is robotically assisted laparoscopic radical prostatectomy less invasive than retropubic radical prostatectomy? Results from a prospective, unrandomized, comparative study. BJU Int 2008;101:1145-9. [CrossRef] [PubMed]

15. Jurczok A, Zacharias M, Wagner S, Hamza A, Fornara $P$. Prospective non-randomized evaluation of four mediators of the systemic response after extraperito- neal laparoscopic and open retropubic radical prostatectomy. BJU Int 2007;99:1461-6.

[CrossRef] [PubMed]

16. Mouraviev V, Nosnik I, Sun L, Robertson CN, Walther $P$, Albala $D$, et al: Financial comparative analysis of minimally invasive surgery to open surgery for localized prostate cancer: A singleinstitution experience. Urology 2007;69:311-314. [CrossRef] [PubMed]

17. Link RE, Su LM, Bhayani SB, Pavlovich CP. Making ends meet: A cost comparison of laparoscopic and open radical retropubic prostatectomy. J Urol 2004; 172:269-274. [CrossRef] [PubMed]

18. Mottet $N$, van den Bergh RCN, Briers $E$, Bourke $L$, Cornford P, De Santis M, et al. Guidelines recommendations for the various disease stages. In: EAU EANM - ESTRO - ESUR - SIOG Guidelines on Prostate Cancer; Prostate cancer update March 2019, European Association of Urology 2019:90.

19. Stolzenburg JU, Rabenalt R, DO M, Ho K, Dorschner W, Waldkirch $E_{\text {, al. Endoscopic extraperitoneal radical }}$ prostatectomy: oncological and functional results after 700 procedures. J Urol 2005;174:1271-5. [CrossRef] [PubMed]

20. Curto F, Benijts J, Pansadoro A, Barmoshe S Hoepffner JL, Mugnier C, et al. Nerve sparing laparoscopic radical prostatectomy: our technique. Eur Urol 2006;49:344-52. [CrossRef] [PubMed]

21. Sacco E, Prayer-Galetti T, Pinto F, Fracalanza S, Betto $G$, Pagano $F$, et al. Urinary incontinence after radical prostatectomy: incidence by definition, risk factors and temporal trend in a large series with a long-term follow-up. BJU Int 2006;97:1234-41. [CrossRef] [PubMed]

22. Augustin $H$, Hammerer $P$, Graefen $M$, Palisaar $J$, Noldus J, Fernandez $S$, et al. Intraoperative and perioperative morbidity of contemporary radical retropubic prostatectomy in a consecutive series of 1243 patients: results of a single center between 1999 and 2002. Eur Urol 2003;43:113-8. [CrossRef] [PubMed]

23. Galli S, Simonato A, Bozzola A, Gregori A, Lissiani $A$, Scaburri A, Gaboardi F. Oncologic outcome and continence recovery after laparoscopic radical prostatectomy: 3 years' follow-up in a "second generation center". Eur Urol 2006;49:859-65. [CrossRef] [PubMed]

24. Lepor $H$, Nieder AM, Ferrandino MN. Intraoperative and postoperative complications of radical retropubic prostatectomy in a consecutive series of 1000 cases. J Urol 2001;166:1729-33. [CrossRef] [PubMed]

25. Rassweiler J, Seemann O, Schulze $M$, Teber $D$ Hatzinger M, Frede T. Laparoscopic versus open radical prostatectomy: Acomparative study at a single institution. J Urol 2003;169:1689-1693. [CrossRef] [PubMed]

26. Bhayani SB, Pavlovich CP, Hsu TS, Sullivan W, Su Li. Prospective comparison of short-term convalescence:Laparoscopic radical prostatectomy versusopen radical retropubic prostatectomy. Urology 2003;61: 612-616. [CrossRef] [PubMed]

27. Su LM, Link RE, Bhayani SB, Sullivan W, Pavlovich CP. Nerve-sparing laparoscopic radical prostatectomy: replicating the open surgical technique. Urology 2004; 64:123-7. [CrossRef] [PubMed]

28. Guillonneau B, el-Fettouh $H$, Baumert $H$, Cathelineau $X$, Doublet JD, Fromont $G$, et al. Laparoscopic radical prostatectomy:oncological evaluationafter 1000 cases at Montsouris Institute. J Urol 2003;169:1261-6. [CrossRef] [PubMed] 
29. Han M, Partin AW, Pound CR, Epstein JI, Walsh PC. Long-term biochemical disease-free and cancerspecific survival following anatomic radical retropubic prostatectomy. The 15-year Johns Hopkins experience. Urol Clin North Am 2001;28:555-65.

[CrossRef] [PubMed]

\title{
LAPAROSKOPSKA RADIKALNA PROSTATEKTOMIJA: ISKUSTVO JEDNOG CENTRA
}

\author{
Baškim Šabani ${ }^{1}$, Ognen Ivanovski ${ }^{1}$, Slobodan Gurmeševski ${ }^{1}$, Gordana Petruševska², \\ Sašo Dohčev ${ }^{1}$, Sotir Stavridis ${ }^{1}$, Oliver Stankov ${ }^{1}$
}

\begin{abstract}
${ }^{1}$ Univerzitet Ćirilo i Metodije, Medicinski fakultet, Univerzitetska klinika za urologiju, Skoplje, Severna Makedonija ${ }^{2}$ Univerzitet Ćirilo i Metodije, Medicinski fakultet, Institut za patologiju, Skoplje, Severna Makedonija
\end{abstract}

Kontakt: Bashkim Shabani

Vodnjanska 17, 1000 Skoplje, Severna Makedonija

E-mail: bashkimshabani7@gmail.com

Minimalno invazivne tehnike, uključujući robotski potpomognutu i laparoskopsku radikalnu prostatektomiju, postale su operativne tehnike izbora za operativno lečenje karcinoma prostate.

Cilj studije bio je proceniti i uporediti rezultate laparoskopske radikalne prostatektomije (LRP) i otvorene retropubične radikalne prostatektomije (ORRP), u pogledu bezbednosti, efikasnosti i onkološkog ishoda.

Ukupno 123 radikalne prostatektomije (RP) za nisko rizični lokalizovani karcinom prostate obavljene su u periodu od januara 2016. do juna 2019. godine, na Univerzitetskoj klinici za urologiju u Skoplju. Od toga je 61 radikalna prostatektomija $(49,6 \%)$ bila LRP, a 62 $(50,4 \%)$ bile su ORRP, uz prosečnu starost bolesnika 54 godine (od 33 godine do 67 godina). Indikacije za operativni postupak bile su: patohistološki nalaz adenokarcinoma prostate, starost $\leq 70$ godina, PSA $<10 \mathrm{ng} / \mathrm{ml}$, Gleson-skor $\leq 7(3+3$ ili $3+4)$, negativna scintigrafija kostiju, stadijum $\leq \mathrm{T} 2 \mathrm{a}$, N0, MO. Svi bolesnici sagledani su kroz demografske podatke, nivoe PSA, Gleason-skor, trajanje operativnog zahvata, konverziju iz LRP u ORRP, gubitak krvi, perioperativne komplikacije, uklanjanje operativnog katetera, transfuziju krvi, boravke u bolnici i onkološki ishod.

LRP se pokazao superiornijim u odnosu na ORRP, što je rezultiralo kraćim operativnim vremenom, manjim gubicima krvi $(p<0,5)$, kraćim vremenom potrebnim za nastavak oralnog unosa hrane i tečnosti, kraćim postoperativnim boravkom u bolnici $(p<0,5)$ i manjim potrebama za analgetskom terapijom. Što se tiče onkološkog ishoda, primetili smo manje pozitivnih resekcionih ivica u grupi LRP $(p<0,5)$. Naši rezultati pokazuju da je, iako obe operativne tehnike predstavljaju bezbedne procedure i pružaju dobar kvalitet operativnog zahvata, LRP pokazala bolje rezultate u pogledu bezbednosti, efikasnosti i onkološkog ishoda.

Acta Medica Medianae 2020;59(3):13-19.

Ključne reči: karcinom prostate, laparoskopska radikalna prostatektomija, otvorena retropubična radikalna prostatektomija 